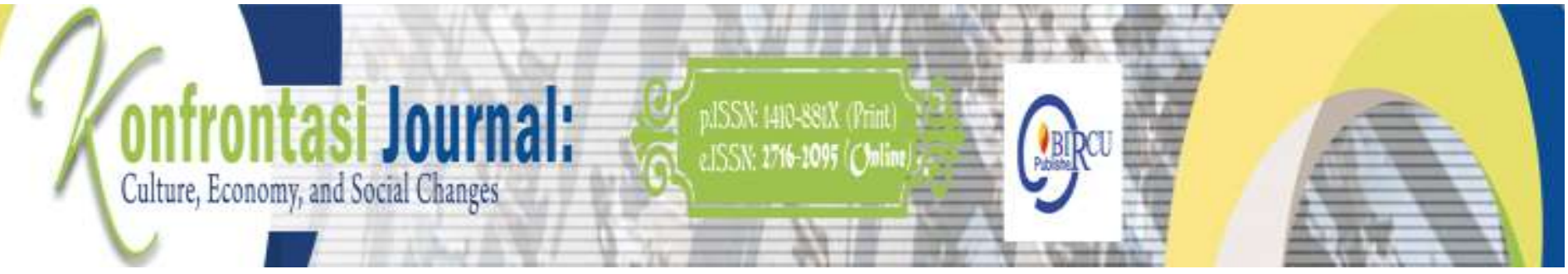

\title{
The Role of Public Relations in Communication Psychology in Government of Provincial North Sumatra
}

\author{
Nurhanifah $^{1}$, Zulfan Kurniadi ${ }^{2}$ \\ ${ }^{1,2}$ Universitas Islam Negeri Sumatera Utara, Indonesia \\ madanicemerlang@gmail.com
}

\begin{abstract}
Communication is a basic thing for humans, since baby we are able to speak or expressing. Communication is an exchange of verbal and non-verbal language between the informant and the recipient of information in order to understand each other for a particular purpose. In this era of advanced and rising technology, every government and commercial institution must be able to keep up with the times, especially in improving the reputation and to broadcast the information. By maintaining good communication and image, the public can see the quality of performance and it affects the work programs implemented by the government. Therefore, this study aims to assess the public relations performance of the North Sumatra Provincial Government in conveying information to the public. This study uses qualitative research methods and through observation techniques. The results of this study indicate that in carrying out its role, the Public Relations of North Sumatra Province carries out two-way communication. Public Relations disseminates the policies and programs of the North Sumatra Provincial Government using communication channels in the form of mass media, both outdoor media in the form of billboards and posters, speeches and presentations, websites, special publications and digital catalogues as well as in connection with other mass media. Public Relations also made efforts to get a response from the public on the performance of the North Sumatra Provincial Government.
\end{abstract}

Keywords

communication;

public relation; north

Sumatra

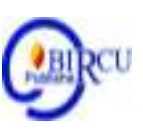

\section{Introduction}

Development is a systematic and continuous effort made to realize something that is aspired. Development is a change towards improvement. Changes towards improvement require the mobilization of all human resources and reason to realize what is aspired. In addition, development is also very dependent on the availability of natural resource wealth. The availability of natural resources is one of the keys to economic growth in an area. (Shah, M. et al. 2020).

Communication is something that is usual thing do by humans and touches all aspects of human life because communication can happen anywhere. A study by Suprapto, 2009 revealed that $70 \%-90 \%$ of our time is used to communicate. Human life always forms communication relationships with other people, because humans live their lives and solve problems by interacting socially with other people. (R Wulandari, 2018).

Communication is the process of delivering messages by someone to other people to tell, change attitudes, opinions or behavior either directly orally or indirectly through the 
Konfrontasi Journal: Culture, Economy and Social Changes, 9 (1) March 2022, 1-6

ISSN: 1410-881X (Print), 2716-2095 (Online)

Nurhanifah, Zulfan Kurniadi: The Role of Public Relations in Communication Psychology in Government of Provincial North Sumatra

DOI: https://doi.org/10.33258/konfrontasi2.v9i1.186

http://www.konfrontasi.net/index.php/konfrontasi2

media. In this communication requires a reciprocal relationship between the delivery of messages and recipients namely communicators and communicants (Hasbullah, et al: 2018).

The purpose of human communication is to produce an effective communication act, namely conveying what is in the mind of the communicator, so that it is the same as what the other party thinks (Supratman, L. \& Mahadian, 2016). However, a person's personality is different from one another (person to person), so that a person's communication style is distinctive and unique. (Y Nurhidayah, 2018). The application of communication psychology is intended so that communication can be effective regardless of differences in one's characteristics and personality.

The concept of human resource development is an attempt to improve technical, theoretical, conceptual, and education and training. The types of development are grouped into informal development and formal development: 1) Informal development, namely employees on their own desires and efforts train and develop themselves by studying literature books that have to do with their work or position. Informal development shows that the employee is eager to advance by improving his work ability. 2) Formal development, where employees are assigned by the company to take part in education and training, both those conducted by the company and those carried out by educational and training institutions. (Setiawan, D and Marfistasari, A. 2021)

Human Resources (HR) is the most important component in a company or organization to run the business it does. Organization must have a goal to be achieved by the organizational members (Niati et al., 2021). Development is a change towards improvement. Changes towards improvement require the mobilization of all human resources and reason to realize what is aspired (Shah et al, 2020). The development of human resources is a process of changing the human resources who belong to an organization, from one situation to another, which is better to prepare a future responsibility in achieving organizational goals (Werdhiastutie et al, 2020).

Human relations are a translation of public relations, it's just that here the nature of the relationship is not like ordinary people communicating, it is not only the delivery of a message by one person to another, but contains very deep psychological elements between other people. Every agency needs a public relations officer to carry out the function of public relations and all matters relating to the community so that they can be handled properly as much as possible. (Rahman, A, 2016). Public assessment of an institution or organization is related to the showing of respect, good and favorable impressions of an organization or company represented by public relations.

Image basis is an individual view or perception given by individuals which will gradually form a broader and abstract opinion which is commonly referred to as an image. (Ruslan, 2005:74) If an organization or company has a good image and mutual understanding, mutual appreciation, mutual confidence, goodwill, it will get support from the public (Ruslan, 2005:74). Public support But on the other hand, if the image of the organization or company is bad, it will not get public support and understanding

The existence of a public relations unit within the government is a must in an effort to disseminate or explain all government activities and work programs aimed at both internal and external public relations. Based on the description above, the authors are interested in conducting a study entitled "The Role of Public Relations in Communication Psychology in Government of Provincial North Sumatra". 


\section{Research Methods}

This research was conducted at the North Sumatra Provincial Government Office. This location was chosen because the Public Relations of the Government of North Sumatra is actively here. This study uses a qualitative research approach. Where qualitative research is a research with a natural setting (naturalistic). Qualitative research methods are physical and non-physical observation research methods based on the philosophy of postpositivism, used to examine the condition of natural objects, (as opposed to experiments) where the researcher is the key instrument. The results of this study are presented in a descriptive narrative form by paying attention to the story progress of the informants who are the research subjects.

According to Sugiyono (2012:13) the characteristics of qualitative research are as follows:

1. It is carried out under natural conditions, (as opposed to an experiment), directly to the data source and the researcher is the key instrument.

2. Qualitative research is more descriptive. The data collected is in the form of words or pictures, so it does not emphasize numbers.

3. Qualitative research emphasizes more on the process than on the product or outcome.

4. Qualitative research conducted inductive data analysis.

5. Qualitative research emphasizes more on meaning.

\section{Discussion}

Along with the rapid development of technology that offers convenience, the delivery of information and communication is carried out in a more efficient way. Public Relations of the Provincial Government uses technology because the public needs fast, broad and accurate information. All of this can be facilitated by advances in information technology and also with the availability of technology, bringing the Government and the people of North Sumatra closer together.

According to the results of observations, the public can easily access the official website available, namely https://sumutprov.go.id, in which there is a lot of information, news and even the public can submit complaints quickly. This was conveyed by the Acting Governor of North Sumatra (Pj Gubsu) Drs Eko Subowo MBA in his written remarks "With the support of information technology, all implementation of superior programs of each regional apparatus organization (OPD) and activities of the Provincial Government can be reported directly to the public so that all can be known the public and the community and can also evaluate the benefits of an activity by providing feedback, comments and input on the activities carried out," he said at the opening of the Public Relations Coordination Meeting (Rakor) for the North Sumatra Provincial Government (Pemprovsu) with Regency / City Governments throughout North Sumatra ( North Sumatra). (sumutprov.go.id, July 25, 2018)

There is an important difference between the functions and operations of public relations in government agencies and commercial institutions, namely that government agencies do not have a commercial element in them, although government public relations also do the same in publication, promotion and dissemination activities. Through the public relations unit, the government can convey information or explain its program regarding policies and actions in carrying out its government duties or obligations. In its functions and operations, the Public Relations of the Provincial Government is in charge of maintaining good communication, maintaining good morals and image and serving the community in 
order to achieve the goals of government agencies. In essence, the function of public relations is to serve the community, maintain good communication, and emphasize good morals and behaviour. This is not much different from what is done by the Public Relations of the Provincial Government.

There are several things that need to be considered by Public Relations in government agencies / institutions to carry out their main tasks, namely:

a. Observing and studying the desires, and aspirations contained in society (learning about public desires and aspiration).

b. The activity of providing advice or giving suggestions in response to what government agencies/institutions should do as desired by the public.

c. The ability to seek the creation of satisfactory relations between the public and government officials (ensuring satisfactory contact between public and government officials).

d. Provide information and information about what an agency/government agency has been trying to do (informing and out what an agency is doing).

e. Able to keep confidence and trust and invite the community to participate or participate in the implementation of development programs in various fields, social, cultural, economic, political as well as maintaining national stability and security.

f. Honesty in the service and dedication of the relevant government apparatus needs to be maintained and maintained in carrying out their respective duties and obligations. (Ruslan, 2016: 108).

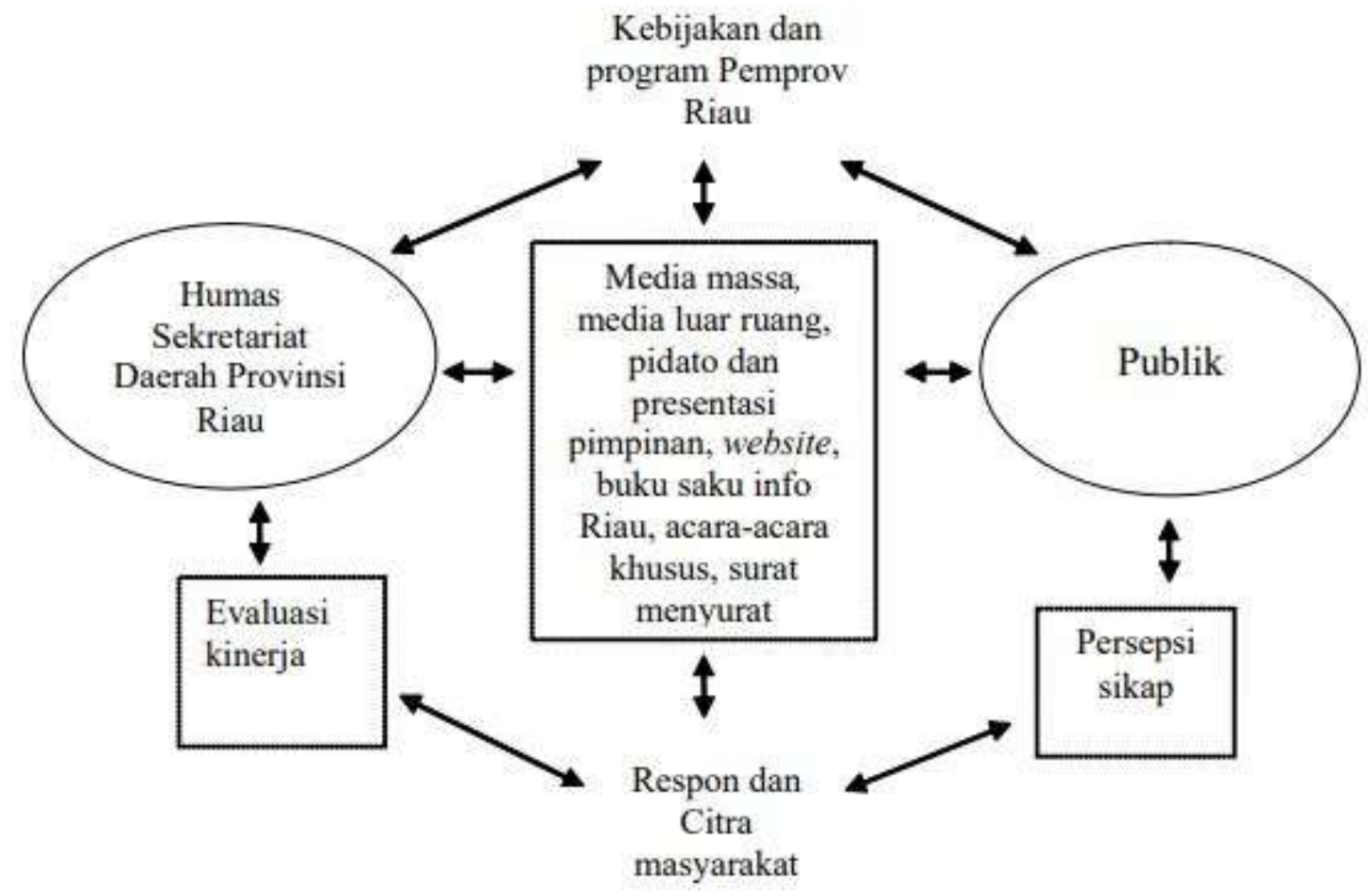

Figure 1. The Role of Public Relations of the Regional Secretariat of Riau Province in Formation of a Positive Image of the Government of Riau Province

(Source: Results of data processing, 2008) (Lubis, 2012) 
In carrying out its role, Public Relations of North Sumatra Province actually conducts two-way communication. Public Relations conveyed the policies and programs of the North Sumatra Provincial Government using communication channels in the form of mass media, both outdoor media in the form of billboards and posters, speeches and presentations from leaders, websites, special publications, digital catalogues as well as relations with other mass media. Public Relations also made communication efforts to get a response from the public to the North Sumatra Provincial Government.

\section{Conclusion}

Communication is a description of how to convey information or messages either by a person or group, organization, and community with the media or directly, to other people and the effects of the results of the communication that will be connected with the environment and other people. One of the professions of Communication Science is Public Relations or commonly referred to as public relations. The existence of Public Relations in a government agency can be a bridge between the government and to public.

The main tasks and functions of government public relations cannot be separated from image formation. Likewise, with the Public Relations of the Province of North Sumatra, where the activities carried out by the Public Relations of the Province of North Sumatra cannot be separated from the efforts to form the image of the Government of the Province of North Sumatra in the eyes of the public. A positive image is the main goal that must be achieved by the provincial government, especially by the governor who will determine the continuity of the power he has or is called a performed image, which is more aimed at the subject, how the appearance of the government leaders which will then indirectly shape the image of the government as a whole (corporate image).

\section{References}

Apriliana, T. R., Musta'an, M. A., \& Wisudawanto, R. (2017). Strategi dan Hambatan Humas Polresta Surakarta dalam Pemanfaatan Media Sosial (Instagram) (Doctoral dissertation, Universitas Sahid Surakarta).

Hasbullah, et al. (2018). Communication Pattern of Wilayatul Hisbah, Lhokseumawe City in Implementing Amar Makruf Nahi Mungkar. Budapest International Research and Critics Institute-Journal (BIRCI-Journal).P. 194-205.

Humas Punya Peran PentingDi Era Digital. Diunduh di https://sumutprov.go.id/artikel/artikel/humas-punya-peran-penting-di-era-digital. Tanggal 28 Desember 2021

Lubis, E. E. (2012). Peran humas dalam membentuk citra pemerintah. Jiana (Jurnal Ilmu Administrasi Negara), 12(1).

Niati, D. R., Siregar, Z. M. E., \& Prayoga, Y. (2021). The Effect of Training on Work Performance and Career Development: The Role of Motivation as Intervening Variable. Budapest International Research and Critics Institute (BIRCI-Journal): Humanities and Social Sciences, 4(2), 2385-2393. https://doi.org/10.33258/birci.v4i2.1940

Nurhidayah, Y., \& Nurhayati, E. (2018). Psikologi Komunikasi Antara Gender.

Palulun, Y. et al. (2021). Analysis of Readiness to Use Target Costing Method in Production Cost Efficiency Efforts at Risha Bakery. Budapest International Research and Critics Institute-Journal (BIRCI-Journal). P. 6385-6395. 
Rahman, A. (2016). Strategi Komunikasi Humas Rumah Sakit Umum Sari Mutiara Medan dalam Membangun Citra Perusahaan (Doctoral dissertation).

Rakhmat, J. (2011). Psikologi komunikasi.

Ruslan, R. (2005). Manajemen Public Relations dan Media Konsepsi dan Aplikasi. Jakarta: PT. Raja Grafindo Persada.

Shah, M. et al. (2020). The Development Impact of PT. Medco E \& P Malaka on Economic Aspects in East Aceh Regency. Budapest International Research and Critics InstituteJournal (BIRCI-Journal). P. 276-286.

Shah, M. M., et al. (2020). The Development Impact of PT. Medco E \& P Malaka on Economic Aspects in East Aceh Regency. Budapest International Research and Critics Institute-Journal (BIRCI-Journal) Volume 3, No 1, Page: 276-286.

Sugiyono. 2012. Metode Penelitian Kuantitatif kualitatif dan R\&D. Bandung: Alfabeta.

Suhendi, Hendi (2012) Strategi humas Disnakertans dalam memperbaiki citra lembaga: Penelitian di Disnakertrans Provinsi Jawa Barat mengenai kasus TKI. Diploma thesis, UIN Sunan Gunung Djati Bandung.

Supratman, L. P., \& Mahadian, A. B. (2016). Psikologi Komunikasi. Deepublish.

Werdhiastutie, A. et al. (2020). Achievement Motivation as Antecedents of Quality Improvement of Organizational Human Resources. Budapest International Research and Critics Institute-Journal (BIRCI-Journal) Volume 3, No 2, Page: 747-752.

Wulandari, R., \& Rahmi, A. (2018). Relasi Interpersonal dalam Psikologi Komunikasi. Islamic Communication Journal, 3(1), 56-73. 